\title{
OUTSOURCING SERVICES IN THE AUTOMOTIVE SECTOR - MARKET OVERVIEW
}

\begin{abstract}
Constantly growing and restrictive requirements of the automotive industry make the ability to react quickly to the customer's needs become very important in the operations of enterprises. Concentrating the company around the final units of the production chain, i.e. customers / buyers, requires constant improvement, and thus enforces changes and reindustrialisation / reorientation in the way businesses operate. The concept of using external companies' services is also a response to the growing market requirements. on order, which indicates the need to compete with the level and quality of service, and above all, increasing competitiveness in terms of efficiency in satisfying the needs of customers. The solution enabling obtaining the required flexibility is the outsourcing of services in the company, consisting, for example, in the implementation of activities related to sorting the product, its assembly, but also quality control, or internal logistics. The paper discusses the market of outsourcing services in the automotive industry and presents the main benefits and threats resulting from the operation of outsourcing companies and the implementation of outsourcing concepts in industry companies. Attention was also paid to the causes of separation of some processes in the automotive industry's production sector, and the analysis and identification of accepted production strategies by automotive sector companies based on the model of flexible production and lean manufacturing.
\end{abstract}

Key words: automotive, downsizing, outsourcing, quality of services

\section{Introduction}

The current need to improve the efficiency of production and services in the automotive sector requires the need to outsource to maintain the high competitiveness of the company. The use of external suppliers' services at particular stages of production, including, for example, sorting, assembly, and quality control in the automotive industry is widespread in the concept of so-called tailor-made (individual) orders [1]. Outsourcing is a modern method of management that allows entities to concentrate on their core business by providing critical and troublesome processes to specialized external companies. Higher levels of the organization's board must ensure the proper functioning of the company on the market, therefore the use of an external outsourcing company to a real extent allows relieving the company's related processes of recruitment, employment, training, quality control, logistics, etc. This therefore concentrates the company and its employees only on the implementation of the main production processes. Modern industrial production is a very well-configured

\footnotetext{
${ }^{1}$ mgr inż, Politechnika Częstochowska, Wydział Zarządzania, doktorantka

${ }^{2}$ dr inż, Politechnika Częstochowska, Wydział Zarządzania, jaroslaw.jasinski@wz.pcz.pl
} 
mechanism, rigidly defined and described in procedures, for example in the ISO system, ensuring the highest and constantly elevated level of quality and, above all, compatible with the customer's order, free from defects and production subassemblies delivered on time. Management and managers very much use the outsourcing companies, which significantly increase their competitiveness and give the opportunity to focus on strategic business goals [2]. Outsourcing is known to many companies that think about the global scale of their operations to gain profits while ensuring production quality. The contemporary fast-changing market affects the shortening of the product life cycle and increases the cost of product life. Enterprises therefore receive pressure to increase competitiveness and profitability. Entrepreneurs pay more attention to innovation and high product quality while at the same time to ensure low costs. Therefore, over time, managers take into account outsourcing practices to maintain an advantage over competitors [1]. Outsourcing relieves the activity of enterprises by delegating secondary duties to external companies that have technology, knowledge and skills. Managers working in the automotive industry must thoroughly understand the essence of outsourcing and the associated risk in order to gain measurable benefits from the practice. Some companies base their decisions on the basis of savings found. Enterprises must, however, assess the situation for several other reasons. The risk of improper purchasing decisions can become a fatal decision reason. Outsourcing services has become an important economic method, and the benefits are huge. Enterprises are trying to reduce operating costs as well as production costs. This is due to lower prices of sold products / details, bringing financial benefits to consumers. By lowering the costs of the product, they risk the loss of quality, thus forcing to withdraw due to a defect and loss of consumers. This, in turn, may harm the organization and potentially the economy of the country in which it produces. Many companies in the automotive industry today spend more money and time on operational issues, but do not spend enough funds for strategic development. Outsourcing is a constantly growing operation in the field of supply chain management in the automotive sector [3].

\section{Benefits and risks associated with outsourcing}

The main benefits resulting from the outsourcing model of cooperation between the production company and the external outsourcing company is the opportunity to benefit from the knowledge and experience of specialists and, above all, to obtain objective information on the products manufactured. An enterprise using the services of an outsourcing company gains access to the best practices and competent staff and employees. A significant advantage of outsourcing is also the simplification of 
management within the organization, and thus also the resignation from subordination and organizational impact or the flattening or hierarchy-downsizing [3]. As a result, the company becomes more flexible, which significantly affects the improvement of quality and creation of new products and solutions [4]. Each company should focus on key well-known processes of its activity, while side tasks should be outsourced to a specialized outsourcing company. According to data, almost $50 \%$ of companies in the automotive sector in Poland outsource quality control services to an external partner $(48 \%)$. In turn, every third company decides to outsource production and assembly and sorting of production elements [5]. In terms of business competitiveness, one of the most important elements is always the right price of the service, which from an economic point of view is lower, the more it suits the customer. Therefore, due to the reduction of costs, almost $34 \%$ of representatives of the automotive sector in Poland use outsourcing services. Another important reason is the significant saving of time $(16 \%)$. Further in the hierarchy is the experience and specialization of the company in a specific field (14\%). Huge benefits make over $50 \%$ of entrepreneurs in the automotive sector permanently use outsourcing services $(57 \%)$. In the event of an emergency situation, as many as $33 \%$ of entrepreneurs admit that they use outsourcing services $(33 \%)$, while $10 \%$ of respondents implement the selected service cyclically and periodically (at certain times of the year). Outsourcing is often associated with the boom during a downturn and during cost reduction. Meanwhile, the research shows that the plants intend to use such services also in a very good situation. The data show that as much as $67 \%$ of the representatives of the automotive sector in Poland are planning to leave the scope of services outsourced to the same extent as before. Every fourth company declares the extension of cooperation, which is a perspective approach for the automotive sector in our country. Manufacturers therefore expect more orders and, therefore, will generate more and increase employment [6]. The benefits of cooperation between companies and outsourcing companies include:

- concentrating the client on the mainstream of its business, which improves results and efficiency,

- reduction of assets and increase of flexibility,

- relieving the board from excessive duties,

- use of economies of scale and synergy,

- increasing the level of reaction to changes in the environment,

- increasing customer satisfaction,

- improving quality and productivity,

- getting access to skills unavailable in the organization,

- reduction of logistic investments,

- development using the potential of a partner,

- cooperation with prestigious partners

- conversion of fixed costs into variable ones,. 
We distinguish strategic, organizational, market and economic goals of outsourcing, including, among others:

- strategic goals: focus on strategic problems, increasing effectiveness, efficiency and flexibility of operations,

- market goals: increase in competitiveness, expanding the scale of operations,

- economic goals: increase in revenues, reduction of costs, improvement of economic results, minimization of economic risk,

- organizational goals: downsizing the organizational structure, simplifying organizational procedures [7].

The analysis of the market for using the services of outsourcing companies shows that the cooperation brings significant savings of operating costs (10-15\%) and working capital at the client $(5 \div 30 \%)$, mainly through the reduction of inventories and better use of time, by reducing purchase costs or more efficient use of resources. Such cooperation brings an increase in income, and due to the improvement of customer service, it also affects the increase in the level of product quality and greater availability. The main advantages and disadvantages of outsourcing are presented in the graphical form.

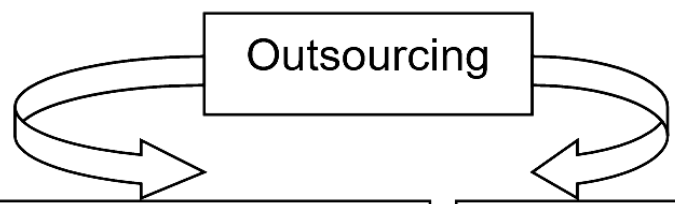

Advantages: Increased competitiveness, improvement of product quality, risk and responsibility sharing, high strategic flexibility, access to modern technologies, knowhow, focus on core business
Disadvantages: dependence on an external company, the possibility of losing control over certain functions, the possibility of losing valuable information, showing the impossibility of performing certain functions, threat of the identity of the company, and as a result competitive advantage because of blurring the boundaries of who and what produces. \\ Fig. 1. Advantages and disadvantages of using external partner services \\ Source: [8]}




\section{The reasons for the separation of outsourcing services}

The production processes play an important role among the business processes implemented in the enterprise. Nowadays, companies, that is, customers not only expect consistent orders and timely orders, but also a quick response to reported complaints. Unfortunately, very often production reporting takes place with a long delay. Therefore, the later any incompatibilities are detected, the higher the costs of removing them. Employee errors are the biggest mistakes, unfortunately one should be aware of the fact that man is not able to avoid all unintentional errors, even despite the use of tools or methods to minimize them [9]. In order to protect the customer from the consequences resulting from irregularities in deliveries and to reduce the operating costs of the organization and increase the flexibility of production processes, the largest companies in the automotive industry very often use the services provided by outsourcing companies. These companies employ employees trained with the necessary technical knowledge who perform their duties at the highest level [10]. Each of the outsourcing projects consists of three components, which are presented in Figure 2.

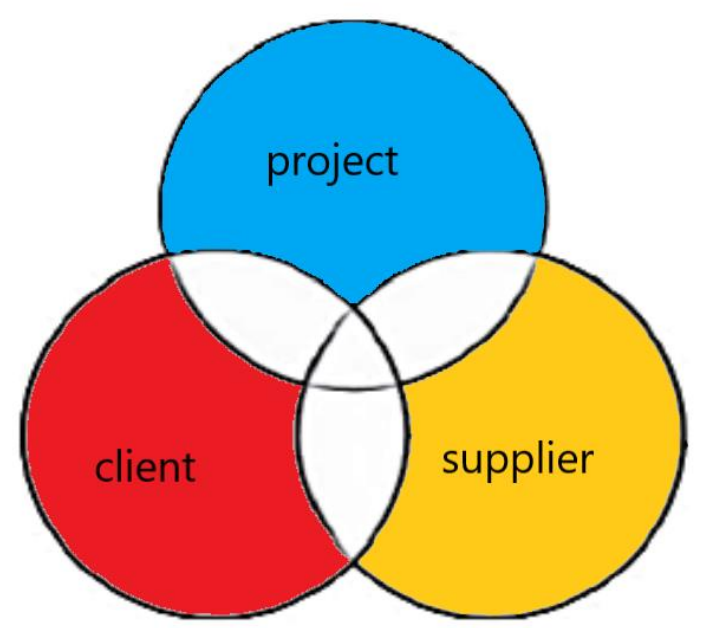

Source: [13]

Fig. 2. Three inherent components of outsourcing

The concept of outsourcing management is first of all requiring the transfer of necessary resources and factors of production to complete the task and the right to make the necessary decisions. The client presents a company transferring resources and factors (which envisage outsourcing the task). The supplier is an organization that performs a given task. The project is a completed and defined scope of activities, 
commissioned work. The customer wants a fast and very qualitive service, while the supplier is interested in achieving high profits [12]. Differences in goals between one and the other require proper behavior between the customer and the supplier when concluding the contract and negotiating the stages of outsourcing. Otherwise it ends with a one of the partners collapse [3].

\section{Outsourcing services in the automotive sector}

Nowadays, quality control plays a special role in the optimization of production processes. Appropriate use of tools and methods to support production allows to fully minimize the risk of incompatible components appearing on the production line, which significantly reduces the costs associated with employing additional employees and production and the need to conduct training for each employee [11]. Production support is characterized by the fact that at the request of companies (clients) employees are delegated to the commissioned work. The employees first undergo training in the scope of activities performed, health and safety trainings and procedures imposed by clients. Employees are familiar with the rules prevailing at the workplace. Another of the outsourcing services is quality control and repair. These works are carried out at the client's premises and include the selection of details, quality control of parts to be produced, inspection of parts on the production line and control of finished products. If the company (customer) has its own procedures and internal instructions, all work is done for compliance with them [10]. The next outsourcing services in the automotive industry are assembly and production works. It brings tangible benefits in the form of reducing employee maintenance costs. Repacking of components / details is an equally common service. Repacking as well as previous services as soon as the customer has an instruction, is carried out in accordance with the company's instructions. Automotive service providers today offer a rich package of services including functions:

- production support by providing employees to production lines. Every employee should have appropriate qualifications if the client requires it in accordance with company instructions. It is a service in difficult conditions and, above all, under enormous time pressure. Specialized companies can quickly specialize their employees in each production line, and at the same time meet often strict quality and quantity requirements (machine / device operator).

- production support in the scope of alternative implementation of production activities resulting from a failure: assembly, sorting most often carried out on the client's premises, which reduces the transport costs to a substitute place of production. This facilitates the client's quality control process. 
- production support in the situation of increased demand for workforce. Depending on the seasonality of the industry, it directly translates into the demand for employees. When working with an external company, you can avoid work and costs associated with recruitment and job rotation. Enterprises gain great flexibility in adapting production to the market demand for goods or services.

- sorting parts and packaging before serving on the production line (in line and of line). Sorting according to needs is done manually or with the support of machines and sorting lines. The service consists of the transport and sorting processes.

- forklifts with operators. Outsourcing companies also offer forklifts with a trained operator for work in a warehouse or at production lines. All employees should have all requirements regarding the process being performed, the required regulations (eg health and safety) or support for dedicated IT solutions (eg SAP).

- functions related to repacking of goods (copaking), services related to packaging, unpacking, repacking of all kinds of products. The service consists in repackaging individual products, eg from a carton box (consultancy, packaging, selection of transport packaging and marking)

- maintenance work - maintenance, cleaning of machinery and equipment [6].

Thanks to outsourcing agreements concluded between the best entrepreneurs and technology suppliers or consultants, organizations create unmatched and comprehensive solutions of the entire supply chain, which brings tangible economic benefits, and impossible to implement by a single supplier.

\section{Summary}

Enterprises in the automotive sector mainly use outsourcing services. In the last decades, outsourcing has become more and more common, many of the activities that were previously performed in the company currently outsourced to the enterprise. The outsourcing method is mainly used to reduce costs by outsourcing a part of the work outside, instead of dealing with it on a regular basis. Improvement of efficiency, quality and cost reduction are the main strategic assumptions of modern plants operating in competitive markets. In order to meet this assumption, it is necessary to focus on the main activity, all other activities should be outsourced if it is profitable and possible). Clients want to use the specialist knowledge of suppliers, as this is the assurance of the best practices. The only issue is the price, which plays an important role, and in principle it is high. The increase in demand is related to the need to provide more details to customers. Thus, to concentrate mainly on key activities, the company will most likely decide to transfer e.g. assembly, sorting into a service with external entities. However, in periods of economic slowdown, companies must face 
the requirement of cost optimization.[8] The company has to find the answer to the question which of the functions of the plant should be entrusted to external entities. The basic activity should always be in the management of the parent enterprise. By focusing on your priority business, you can achieve very good results and gain a high competitive advantage. The essence, however, is choosing the right partner for outsourcing. It is first of all necessary to analyze the options offered by the future partner, bearing in mind the principle that the lowest price offered by the outsourcing company should not be the key choice factor.

\section{Bibliography}

[1] Roehrich J.K.,Outsourcing Management and Practice Within the Automotive Industry. Springer.

[2] Gayc.L PJ., Essiger J., Outsourcing strategiczny. Koncepcja, modele $i$ wdrażanie, Oficyna ekonomiczna, Kraków 2002. , London.

[3] Power M.J., K.C. Desuoza, C. Bonifazi, Outsourcing. Podręcznik sprawdzonych praktyk, MT, Biznes, Warszawa, 2008, s. 16.

[4] Kraśnicka T., Wydzielania funkcji ze struktury firmy-szanse i zagrożenia, "Pracodawca i Pracownik" 2022,nr 11 (67).

[5] Raport kwartalny KPMG w Polsce I PZPM"Branża motoryzacyjna". Edycja Q4/2017.

[6] Opinion survey of Automotive representatives conducted by Exact Systems in May 2014 at a targeted attempt of representatives of companies from the Automotive sector who are Exact Systems customers. Among them are among other car manufacturers, suppliers of automotive parts and components of Tier I and Tier II such as wipers, car windows, roofs, steering columns or security elements. The size of the research sample was 115 respondents. The survey was carried out using telephone interviews (CATI). 5.Young A.M. „Strategic outsourcing” Long range planning”, vol. 29.

[7] Trocki M., Outsourcing: metoda restrukturyzacji działalności gospodarczej, PWE, Warszawa, 2001.

[8] Grabowska J. Politechnika Śląska Wydział Organizacji i Zarządzania Instytut Zarządzania i Administracji, Zeszyty Naukowe Politechniki Śląskiej, 1971.

[9] Ogólnopolskie badanie rynku Outsourcingu 2013, Grant Thotnton Frąckowiak Sp. z o.o.

[10] Collins R., Bechler K., Kimberly P., Silvio, Outsourcing in the Automotive industry: From JIT to Modulat Consortia. European Management Journal. (1997).

[11] Alexander M, Young D." Strategic outsourcing" "Long Range Planning", Vol. 29, No. 1.

[12] Krejner-Nowecka A., Jakość partnerstwa a sukces outsourcingu w przedsiębiorstwie, Przedsiębiorstwo partnerskie, red. M. Romanowska, M.Trocki, Difin, Warszawa 2002.

[13] Power M.J., Desuoza K.C., Bonifazi C., Outsourcing. Podręcznik sprawdzonych praktyk, MT, Biznes, Warszawa, 2008, s. 16 


\title{
USEUGI OUTSOURCINGOWE W SEKTORZE MOTORYZACYJNYM - PRZEGLĄD RYNKU
}

\begin{abstract}
Streszczenie: Rosnące i restrykcyjne wymagania branży automotive sprawiają, że bardzo ważne w działalności przedsiębiorstw stają się zdolność i umiejętność szybkiej reakcji na potrzeby klienta. Koncentrowanie firmy wokół końcowych jednostek łańcucha produkcji tj. klientów / nabywców wymaga ciągłego doskonalenia, a tym samym wymusza wprowadzanie zmian oraz reindustrializacji / reorientacji w sposobie funkcjonowania przedsiębiorstw. Odpowiedzią na rosnące wymagania rynku jest również koncepcja zastosowania usług firm zewnętrznych tzw. na zamówienie, która wskazuje na konieczność konkurowania poziomem i jakością obsługi, a przede wszystkim podwyższaniem konkurencyjności pod względem sprawności w zaspokajaniu potrzeb klientów. Rozwiązaniem umożliwiającym uzyskanie wymaganej elastyczności jest outsourcing usług w firmie, polegający na przykład na realizacji czynności związanych z sortowaniem produktu, jego montażem, ale również kontrolą jakości, czy logistyka wewnętrzną. W artykule omówiono rynek usług outsourcingowych $\mathrm{w}$ branży automotive oraz przedstawiono główne korzyści i zagrożenia wynikające z funkcjonowania firm outsourcingowych oraz wdrażania koncepcji outsourcingu w firmach branżowych. Zwrócono również uwagę na przyczyny wydzielenia, niektórych procesów w sektorze produkcyjnym branży automotive oraz dokonano analizy i identyfikacji przyjętych strategii produkcyjnych przez przedsiębiorstwa sektora automotive, opartych na modelu elastycznej produkcji oraz lean manufacturing.
\end{abstract}

Słowa kluczowe: jakość usług, outsourcing, redukcja zatrudnienia, sektor motoryzacyjny

Date of sending the publication to the Editor: 22.05.2018

The date of the publication's acceptance by the Editorial Board: 26.06.2018 